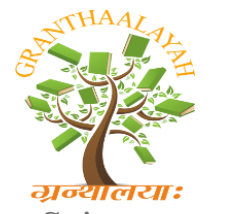

Science
INTERNATIONAL JOURNAL OF RESEARCH -
GRANTHAALAYAH
A knowledge Repository

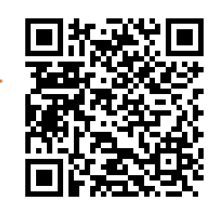

\title{
GROWTH OF TERMINALIA BELLIRICA [(GAERTN.) ROXB.] ON THE MALANJKHAND COPPER MINE OVERBURDEN DUMP SPOIL MATERIAL
}

\author{
Jyotish Katare ${ }^{1}$, Mohnish Pichhode ${ }^{2}$, Kumar Nikhil ${ }^{3}$ \\ ${ }^{1,2}$ Department of Biotechnology, Sardar Patel College of Technology, Balaghat, Madhya \\ Pradesh, INDIA \\ ${ }^{3}$ Principal Scientist, EMG, CSIR- CIMFR, Dhanbad, Jharkhand, INDIA
}

\begin{abstract}
Copper Mining at Malanjkhand copper mining project (MCP), Balaghat, Madhya Pradesh is a subsidiary of Hindustan Copper Limited (HCL), major source of copper and more than $70 \%$ is being contributed from this mines. Copper contamination issues are becoming increasingly common in India with many documented cases of copper metal toxicity in mining sites. Effect of Copper on vegetation was studies by growth of Baheda (Terminalia bellirica) with different combination of soil, copper over burden dump spoil and cowdung manure. This paper in brief reflected that the growth of this plant species significantly improved with the combination of soil and organic manure like cowdung applied in the different combination with copper mine overburden dump spoil material which will be helpful in the revegetation program of these type of wastelands.
\end{abstract}

Keywords:

Malanjkhand Copper mining project, copper over burden dump spoil, Plant growth, Terminalia bellirica [(Gaertn.) Roxb.].

Cite This Article: Jyotish Katare, Mohnish Pichhode, and Kumar Nikhil, "GROWTH OF TERMINALIA BELLIRICA [(GAERTN.) ROXB.] ON THE MALANJKHAND COPPER MINE OVERBURDEN DUMP SPOIL MATERIAL" International Journal of Research Granthaalayah, Vol. 3, No. 8(2015): 14-24. DOI: 10.29121/granthaalayah.v3.i8.2015.2957.

\section{INTRODUCTION}

Mining is an important part of economy. The impact of the copper mines and industry on the surrounding vegetation has been widely investigated although research on the effects of copper mine over burden dump spoil and dust pollution of attention as that given to phytotoxic pollutants. Copper is a ubiquitous pollutant in the environment due to the emission and atmospheric deposition of metal dust released by mining and human activities also. In addition soils may contain elevated levels of copper because of its widespread use as a mining sites overburden dump spoil, land application of sewage sludge as well as smelting activities [1]. 
The selection of baheda plant as a medicinal plant is with the aim that the demand for aromatic medicinal plants is increasing worldwide due to their beneficial effects on long-term health of humans and can be also used to effectively treat human diseases with either low or no side effects [2]. Heavy metal stress is one of the major abiotic stresses that cause environmental pollution persist for a long time in the environment and cause soil pollution and produce phytotoxicity in plants and enter the food chain [3]. Agriculture and the environment were get affected from problem of copper toxicity due to sewage sludge application, dust from smelters, industrial waste and polluted watering practices in agricultural lands [4]. Within the agricultural soils pollutants, $\mathrm{Cu}+2$ have become increasingly hazardous as a component of fungicides, fertilizers and pesticides [5] in which heavy metal uptake by the plants is therefore, a main pathway of metal transfer from sediments and water to the food web. Copper is essential for growth and development of plants as a component of various proteins [6] and acts as a structural element in certain metalloproteins, many of which are involved in electron transport in chloroplasts and mitochondria as well as in oxidative stress response [7]. The importance of this pathway is that $20 \%$ of the carbon fixed by plants flows through it under normal growth conditions [8]. Withania somnifera, an aromatic medicinal plant, is widely considered as the Indian ginseng and in Sanskrit called Ashwagandha, belongs to family Solanaceae, and grows in semi-arid regions of India. In Ayurveda, it is classified as a rasayana (rejuvenation) and expected to promote physical and mental health, rejuvenate the body in debilitated conditions. Ashwagandha is used to treat a number of disorders that affect human health which have been well documented [9]. This study was investigates the effects of $\mathrm{Cu}+2$ stress on growth parameters, membrane electrical conductivity, chlorophyll and carotenoids content, lipid per oxidation and total phenol content in W.somnifera. This may provide a better understanding of tolerance threshold and additional information on the mechanisms of heavy metal tolerance of plants [10].

Copper is an essential micronutrient for normal plant metabolism [11]. Copper is involved in a number of physiological processes such as the photosynthetic and respiratory electron transport chain [12] and as a cofactor or as a part of the prosthetic group of many key enzymes involved in different metabolic pathways, including ATP synthesis [13].

This paper brief studied the growth of Baheda $\{($ Terminalia bellirica $)$ [(Gaertn.) Roxb.] $\}$ on the over burden dump spoil combined with different ratio of soil and organic manure like cowdung in the pot experiment, applied with randomized block design. Significant height and girth increment was noted on the growth of Terminalia bellirica in the different combination of copper overburden dump spoil with soil and cowdung manure ratios. This study ultimately helpful in the re-vegetation and dump spoil stability program of MCL, HCL piled nearby causing major environmental threat and pollutions to nearby.

\section{MATERIALS AND METHODS}

\subsection{SITE DETAILS}

The copper overburden dump spoil material was taken from Malanjkhand Copper Project situated at Malanjkhand in the Mohgaon Panchayath of Baihar tehsil under district Balaghat, Madhya Pradesh (Table.2.1). Malanjkhand referred to as MCP (Malanjkhand copper project) of Hindustan Copper Limited (HCL), Govt. of India undertaken is an open-pit copper mine in India, located near the town of Malanjkhand, 90 km northeast of Balaghat in Madhya Pradesh (Fig.2.1). 
Table.2.1: Location coordinates of Malanjkhand Mine, Padritola, Baihar Tehsil, Balaghat District, Madhya Pradesh, India

\begin{tabular}{|l|l|}
\hline Latitude \& Longitude : & $22^{\circ} 1^{\prime}$ North, $80^{\circ} 43^{\prime}$ East \\
\hline Latitude \& Longitude (Decimal Degrees): & 22.0166666667 \\
\hline Latitude \& Longitude (Degrees plus Decimal \\
Minutes):
\end{tabular}
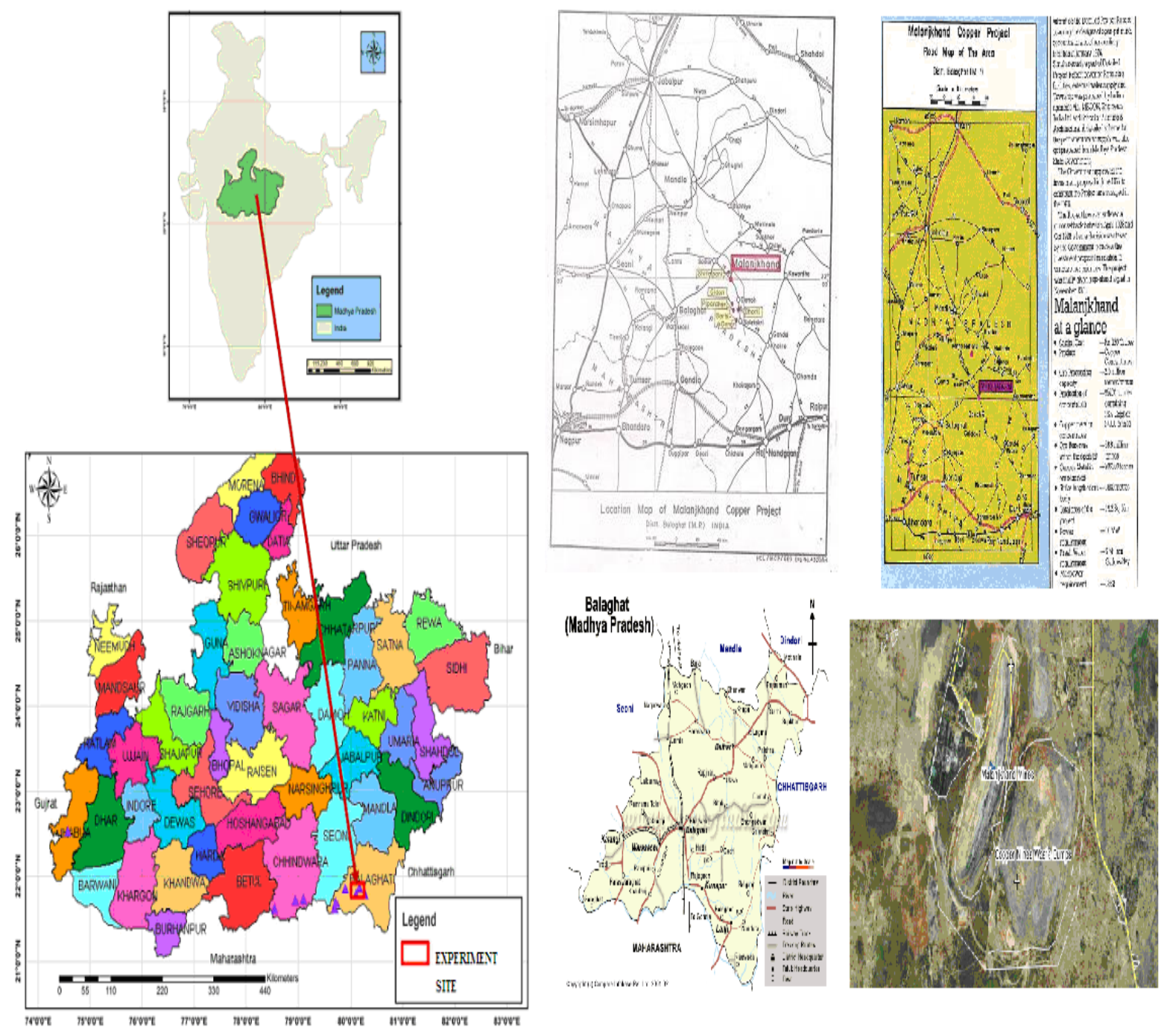

Figure.2.1: Location Map (Source: MCP, HCL; Map India; Manganese Mines Report of Balaghat)

\subsection{EXPERIMENT LAYOUT \& DESIGN}

The soil and over burden dump spoil material was collected from MCP site, Malanjkhand, district balaghat, M.P, poured in different pots with various ratios of soil, over burden dump spoil and cowdung. All 90 saplings of Baheda (Terminalia bellirica) plants of $3 \mathrm{~cm}$ height and $0.12 \mathrm{~cm}$ girth 
was transplanted in different pots with statistically randomized block design in which nine (9) treatments each having 10 replications (Table.2.2). The growth after 90 days was noted. The chemical characteristics like $\mathrm{pH}$, Electrical conductivity (EC) in mmhos/cm, Organic carbon (OC) in $\%$ and available (Avl.) nitrogen $(\mathrm{N})$, Phosphorus $(\mathrm{P})$ and Potassium $(\mathrm{K})$ in $\mathrm{kg} / \mathrm{ha}$ were tested for copper overburden dump spoil and soil materials combined with different ratios.

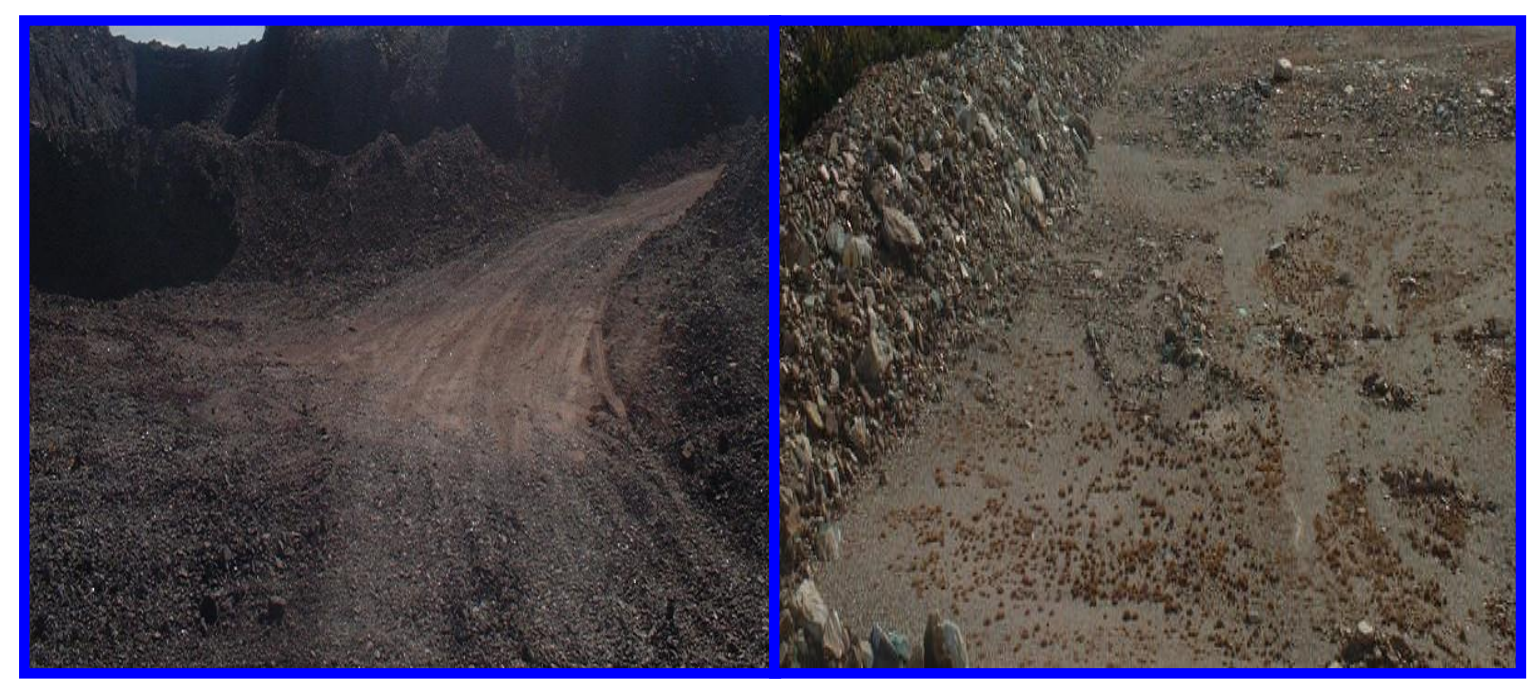

Figure.2.2: Copper Overburden Dump Spoil at Malanjkhand Copper Project
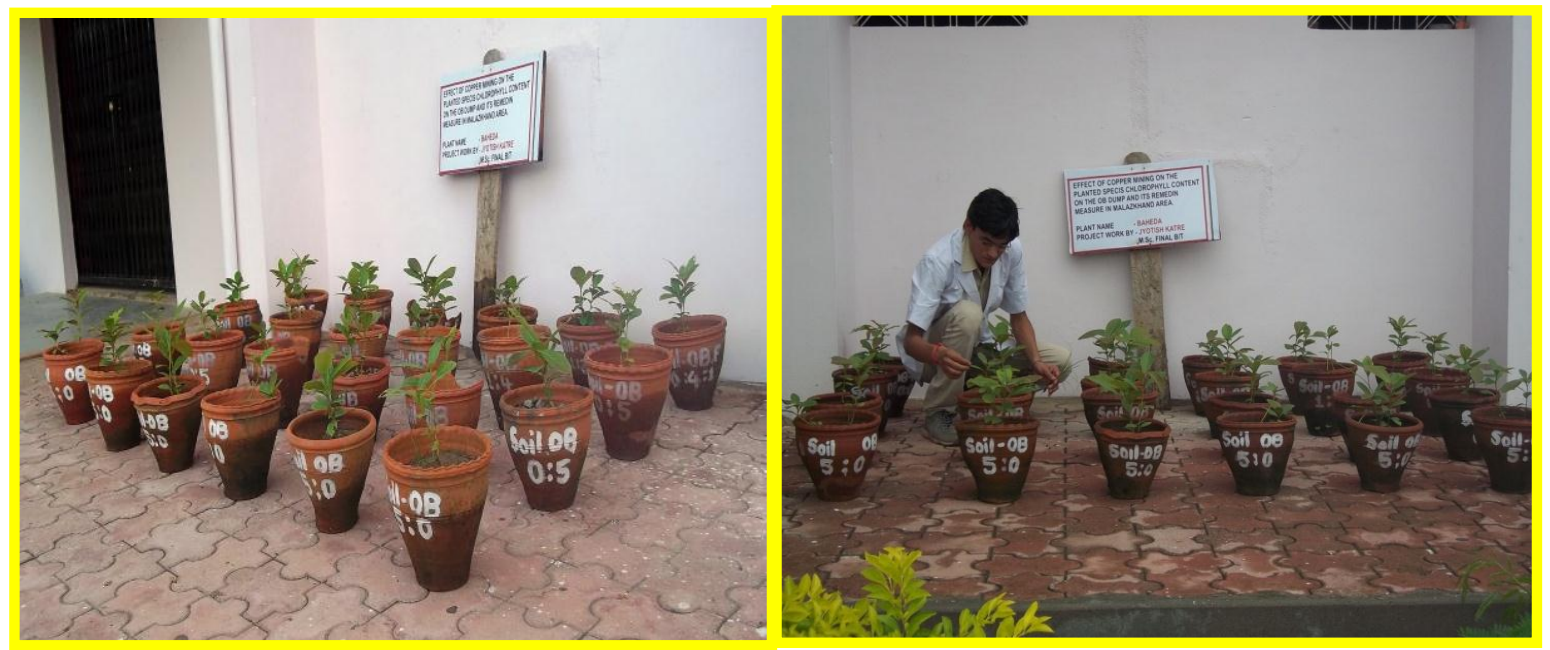

Figure.2.3: Layout Design of the Pot Experiment

All the 8.0 inches diameter and 9.0 inches height measuring ninety (90) pots were filled with a total of $8 \mathrm{~kg}$ material either soil or copper overburden dump spoil material (Cu OBD spoil material) and in combination of both with $1 \mathrm{~kg}$ of cowdung as organic manure (Soil:Spoil:Cowdung). The different treatments are on the basis of combination or ratios of these three materials (0:0:0) with a maximum of 4 (Fig.2.2 and 2.3): 
Table.2.2: Details of Treatments layout in pot experiment

\begin{tabular}{|l|l|l|l|}
\hline $\begin{array}{l}\text { S. } \\
\text { N }\end{array}$ & $\begin{array}{l}\text { Treatment } \\
\text { Name }\end{array}$ & Particulars & Ratio \\
\hline 1. & S1 & Soil with no copper overburden dump spoil material and cowdung & $4: 0: 0$ \\
\hline 2. & S2 & Copper overburden dump spoil material with no soil and cowdung & $0: 4: 0$ \\
\hline 3. & S3 & Soil with copper overburden dump spoil material and no cowdung & $3: 1: 0$ \\
\hline 4. & S4 & Soil with copper overburden dump spoil material and no cowdung & $2: 2: 0$ \\
\hline 5. & S5 & Soil with copper overburden dump spoil material and no cowdung & $1: 3: 0$ \\
\hline 6. & S6 & $\begin{array}{l}\text { Soil with cowdung and no copper overburden dump spoil } \\
\text { material }\end{array}$ & \\
\hline 7. & S7 & Soil with cowdung and copper overburden dump spoil material & $2: 1: 1$ \\
\hline 8. & S8 & Soil with cowdung and copper overburden dump spoil material & $1: 2: 1$ \\
\hline 9. & S9 & copper overburden dump spoil material with cowdung and no soil & $0: 3: 1$ \\
\hline
\end{tabular}

\subsection{DETAIL OF BAHEDA \{}

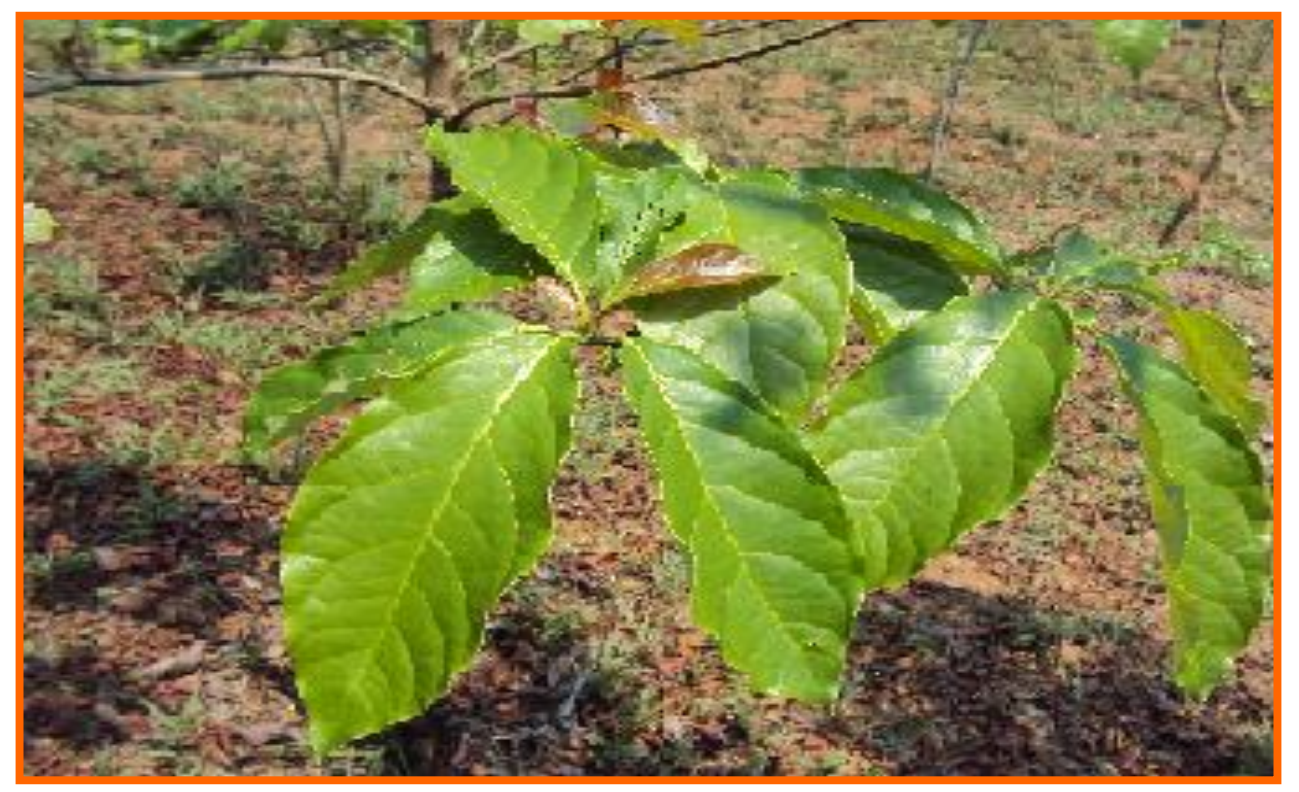

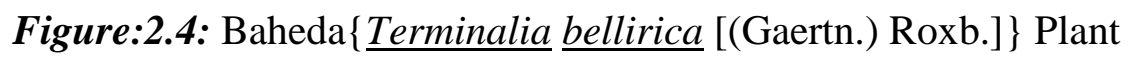

Botanical Name(s): Beleric, Belliric Myrobalan, Baehra, Family Name: Combretaceae, Kingdom: Plantae, Division: Magnoliophyta, Class: Magnoliopsida, Order: Myrtales, Family: Combretaceae, Genus: Terminalia, Species: T. bellirica, Popular Name(s): Beleric Myrobalan, Bibhitaki, Bahera, Bahira, Bilhitak, Baheda, Vibhidhaka, Bastard Myrobalan, Bedda Nut., Parts Used: Fruit., Habitat: Grown throughout India.

\section{DESCRIPTION}

Beleric is a large deciduous tree found throughout India, in areas up to an altitude of 1,000 meters. 
The tree takes a height of 30 meters, while the bark is brownish grey in color. The alternate, broadly elliptic leaves are clustered towards the end of the branches (Figure.2.4). They are 10 to $12 \mathrm{~cm}$ in length and 7 to $14 \mathrm{~cm}$ in breadth. The simple, solitary flowers are in auxiliary spikes, with offensive odor. They blossom in the month of May. The fruits are ovoid grey drupes and the kernels are sweet, but narcotic. The tree is found in abundance in Madhya Pradesh, Uttar Pradesh, Punjab and Maharashtra. It is known as vibhitaki, karshaphala and kalidruma in Sanskrit and bahera in Hindi.

\section{PLANT CHEMICALS}

Sitosterol, gallic acid, ellagic acid, chebulagic acid, galloyl glucose, fatty acid, protein, oxalic acid, tannin, palmitic acid, oleic acid, linoleic acid, galactose, glucose, ethyl gallate.

\section{USES \& BENEFITS OF BAHEDA}

- Beleric is a rejuvenative and laxative. It proves beneficial for hair, throat and eyes.

- Beleric seed oil or fruit paste is applied on swollen and painful parts.

- The seed oil gives excellent results in skin diseases and premature graying of hair.

- Fruit pieces are baked and chewed for cough, cold, hoarseness of voice and asthma.

- Beleric fruit is powdered and used to dress wounds to arrest the bleeding.

- Beleric fruits and kernels are used in making medicated hair oil, used to alleviate pain and burning sensation, boost hair growth and impart black color to the hair.

- The paste of the fruit is applied on eyelids, in case of conjunctivitis.

- The herb is used in various eye ailments, such as myopia, corneal opacity, pterigium, immature cataract, chronic and acute infective conditions.

- Beleric helps in loss of appetite, flatulence, thirst, piles and worms.

- The ripened fruit acts as an astringent and anti-diarrheal.

- The decoction of the kernels is used in case of excessive thirst and vomiting.

- Beleric plant alleviates cough, relieves blocked phlegm, controls bleeding in the sputum and eases bronchospasms.

- It prevents ageing, imparts longevity, boosts immunity, improves mental faculties and enhances the body resistance against diseases.

- It helps in lowering cholesterol and blood pressure.

\subsection{METHODS}

All standards methods adopted for soil sampling and chemical parameters testing by Indian Council of Agriculture Research (ICAR), New Delhi. The methodology adopted for measurement of plant height and girth with meter rule (brand RUMOLD, Nr. 659 ZEICHEN-UND SCHNEIDELINEAL), while stem girth was measured with micrometer screw gauge (brand DRAPER, Made in Japan).

\section{RESULTS AND DISCUSSIONS}

The data were statically analyzed by central tendency and standard deviation of the growth of plant sample of pure soil, copper over burden dump, and both of mixture in different ratios. 


\subsection{GROWTH OF TERMINALIA BELLIRICA PLANT}

The study was conducted for growth of Terminalia bellirica grown in the pots with different ratios of overburden dump and soil with cowdung as organic manure amendment was measured after 90 days. The height of the plant grown in pure soil was having highest average height of $18.76 \mathrm{~cm}$ with $1.33 \mathrm{~cm}$ girth followed by $16.36 \mathrm{~cm}$ in 1:2:1, ratio in treatment $S 8$ with girth thickness of $0.93 \mathrm{~cm}$ respectively. Whereas, in treatment $\mathrm{S} 9$ the growth was very near to $\mathrm{S} 8$ in height but the girth increment were more than $\mathrm{S} 8$ values. The lowest growth was noticed in treatment $\mathrm{S} 2$ in which only $\mathrm{Cu}$ OBD spoil materials was taken in the pots and the height and girth increment was found to be 9.86 and $0.33 \mathrm{~cm}$ respectively (Fig.3.1).

Table.3.1: Height \& Girth (in $\mathrm{cm}$ ) of Terminalia bellirica after 90 days of growth

\begin{tabular}{|l|l|l|}
\hline Treatments & Height $(\mathrm{cm})$ & Girth $(\mathrm{cm})$ \\
\hline S1 & 18.76 & 1.33 \\
\hline S2 & 9.86 & 0.33 \\
\hline S3 & 13.33 & 0.83 \\
\hline S4 & 14.87 & 0.67 \\
\hline S5 & 11.11 & 0.91 \\
\hline S6 & 13.33 & 0.79 \\
\hline S7 & 15.94 & 1.07 \\
\hline S8 & 16.36 & 0.93 \\
\hline S9 & 16.15 & 1.21 \\
\hline
\end{tabular}

Effect of different treatments on height and girth (in $\mathrm{cm}$ ) of Baheda plant in pot experiment

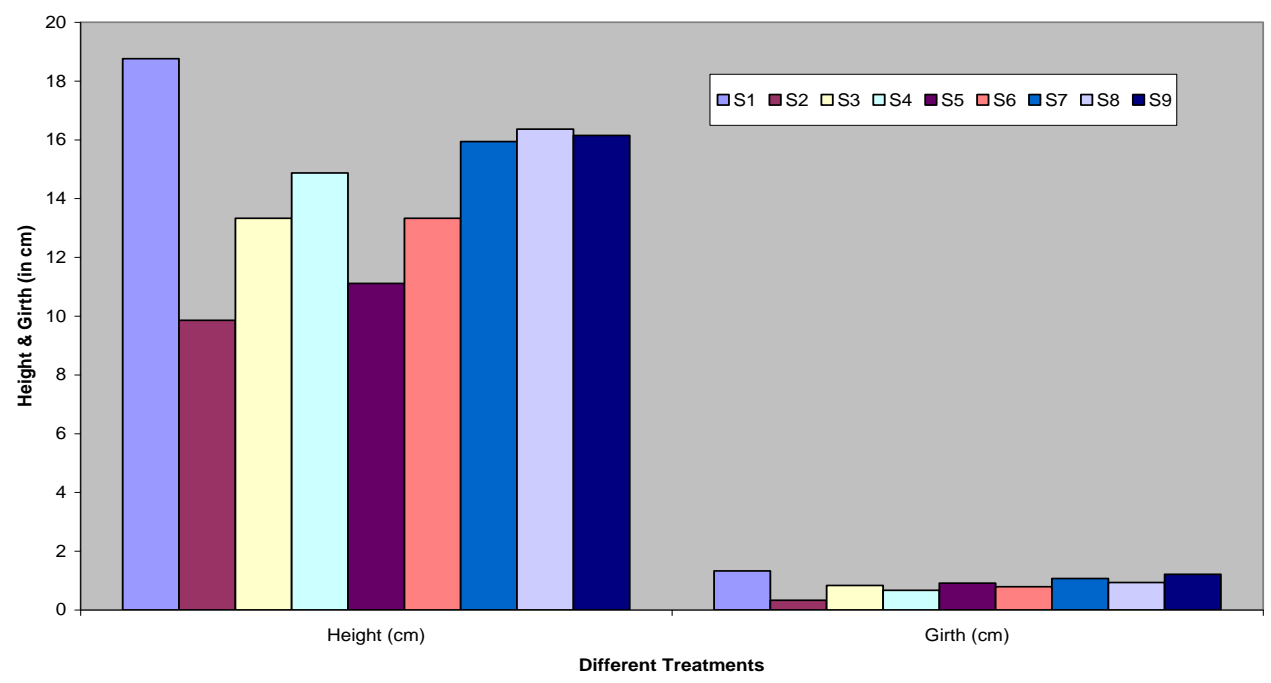

Figure.3.1: Effect of Different Treatments on the Height \& Girth (in $\mathrm{cm}$ ) of Terminalia bellirica after 90 days of growth in pot experiment

Growth analysis is fundamental to the characterization of plant's response to environmental stress. It is reported that roots growth is highly affected by $\mathrm{Cu}+2$ than stems and leaves. This might be 
due to a high $\mathrm{Cu}+2$ supply usually tends to decrease root growth before stem growth, because of preferential copper accumulation in that organ [14] and is considered as a very sensitive indicator to heavy metal exposure [15]. Some findings had suggested that W.somnifera is highly sensitive to elevated $\mathrm{Cu}+2$ concentrations which strongly inhibit the normal growth and development. This had also been reported by eminent Scientist that stem and root growth get reduced along with decline in photosynthetic pigment formation in plants under $\mathrm{Cu}+2$ stress [16]. In this experiment it was also observed that in copper overburden dump spoil material contains copper which inhibits the growth of baheda plant grown after 90 days. Moreover, when soil and cowdung was mixed in certain ratios to the copper overburden dump spoil materials its adverse effect was minimized on the growth of baheda plant (Table.3.1).

\subsection{CHEMICAL CHARACTERISTICS OF DIFFERENT TREATMENTS}

The chemical characteristics like pH, Electrical conductivity (EC), Organic carbon (OC), available Nitrogen $(\mathrm{N})$, Phosphorous $(\mathrm{P})$, and Potassium $(\mathrm{K})$ was found different in all the treatments analyzed for pot materials. The $\mathrm{pH}$ was found to be slightly acidic due to presence of copper and other heavy metals in the spoil material. The electrical conductivity was more when both soil and spoil were present alone i.e. in S1 and S2 treatments of 0.56 and $0.55 \mathrm{mho} / \mathrm{cm}$ respectively. Further, the organic carbon content was found to be more in soil alone S1 treatment and S4 treatment where soil and spoil in equal ratio $2: 2$ by maximum of $1.80 \%$. Available NPK concentration was minimum in S2 treatment where spoil material alone without any combination. Though, available nitrogen was $240 \mathrm{~kg} / \mathrm{ha}$ which was equal to soil mixed with spoil in 3:1 and 1:3 ratios respectively. Whereas, available phosphorus was found medium of $27 \mathrm{~kg} / \mathrm{ha}$ in S3 treatment soil is more in 3:1 ratio. Finally, the available potassium is lowest in spoil alone in $\mathrm{S} 2$ treatment of $146 \mathrm{~kg} / \mathrm{hec}$ low in range and highest in $\mathrm{S} 1$ soil alone of $302 \mathrm{~kg} / \mathrm{ha}$ medium in range respectively (Table.3.2).

In present experiment it was found that if soil as growing media it had shown the neutral $\mathrm{pH}$, maximum of EC, OC and available NPK for plant growth. Moreover, alone copper spoil is not very week material to support plant growth (Fig.3.2 and 3.3). However, if the soil and $\mathrm{Cu}$ spoil in $3: 1,2: 2$ and 1:3 mixed in ratios, helped by improving the chemical characteristics resultant in better medium for the plant growth for this type of contaminated land. This will surely help in understanding the better amelioration and re-vegetation program to be made for the Malanjkhand Copper Mine Overburden Dump spoil and selection of medicinal plant like beheda for the plantation program which will have medicinal and economical properties.

Table.3.2: Chemical analysis of soil and spoil in different combination filled in pot for growing baheda plant.

\begin{tabular}{|l|l|l|l|l|l|l|l|}
\hline $\begin{array}{l}\text { S. } \\
\text { No. }\end{array}$ & Treatment & pH & $\begin{array}{l}\text { EC } \\
(\mathbf{m h o / c m})\end{array}$ & OC (\%) & $\begin{array}{l}\text { Avl. N } \\
(\mathbf{k g} / \mathbf{h e c})\end{array}$ & $\begin{array}{l}\text { Avl. } \\
(\mathbf{k g} / \mathbf{h e c})\end{array}$ & $\begin{array}{l}\text { Avl. K } \\
(\mathbf{k g} / \mathbf{h e c})\end{array}$ \\
\hline 1 & S1 & 7.11 & 0.56 & 1.80 & 600 & 09 & 302 \\
\hline 2 & S2 & 6.86 & 0.55 & 1.20 & 360 & 09 & 146 \\
\hline 3 & S3 & 6.94 & 0.28 & 0.60 & 240 & 27 & 269 \\
\hline 4 & S4 & 6.94 & 0.28 & 1.80 & 600 & 09 & 224 \\
\hline 5 & S5 & 6.71 & 0.25 & 0.60 & 240 & 09 & 190 \\
\hline
\end{tabular}


There was no any significant coorelation were observed between the $\mathrm{pH}, \mathrm{EC}, \mathrm{OC}$, Available $\mathrm{N}$ and K. Similarly it was also found that no relationship between organic carbon and available $\mathrm{Cu}$ in Gujrat soils [17]. They also pointed out that copper is less susceptaible to change in $\mathrm{pH}$ than other micronutrients. Such divalent relationship between $\mathrm{pH}$ and available $\mathrm{Cu}$ also been reported by a number of investigators [18] [19]. Similar relationship of $\mathrm{Cu}$ with $\mathrm{pH}$ and EC was reported [20]. The negative coorelation between $\mathrm{Cu}$ and organic carbon also observed [21] [22]. The significant negative correlation was observed with available phosphorus observed in West Bengal[23].

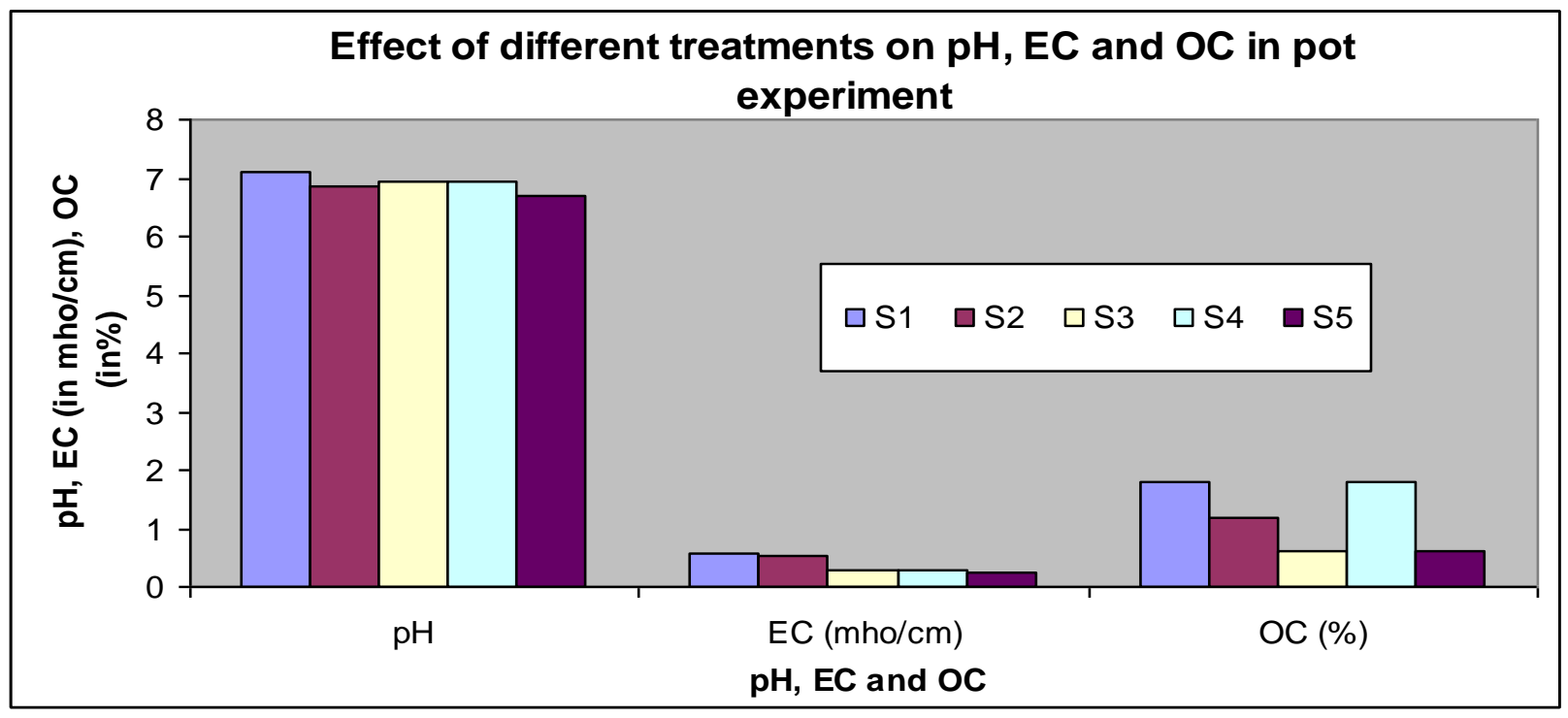

Figure.3.2: Effect of Different Treatments on the availability of $\mathrm{pH}, \mathrm{EC}$ and $\mathrm{OC}$ in pot experiment

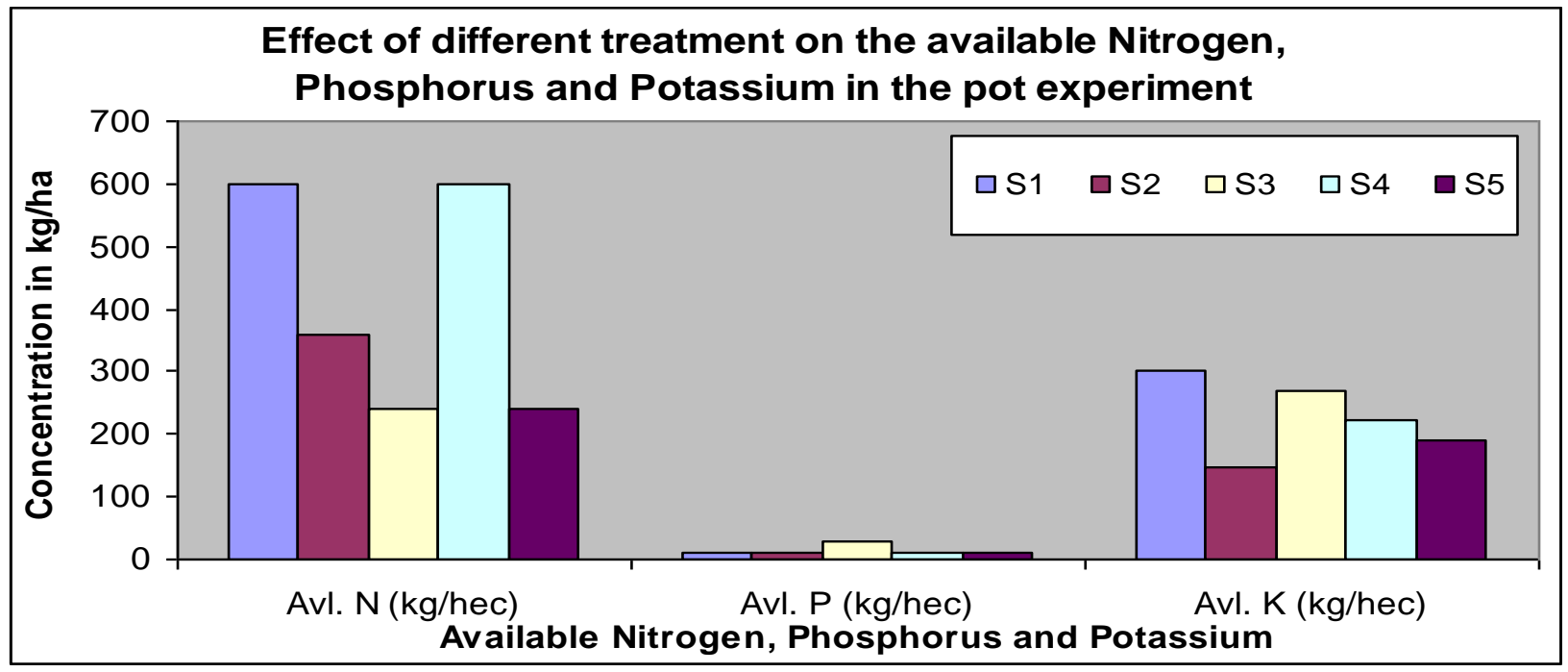

Figure.3.3: Effect of Different Treatments on the availability of available NPK in pot experiment 


\section{CONCLUSION}

The experiment conducted with an objective to fulfill the minimum soil and other organic amendment for the plantation of copper overburden dump spoil and selection of economical viable plantation for the improvement of deteriorated environment [24] [25] [26] due to copper mining in the Malanjkhand Copper Project (MCP) a subsidiary of Hindustan Copper Limited (HCL).

The Terminalia bellirica (Baheda) taken for the experiment had shown significant growth and no other adverse symptom on the plant. The soil and spoil combination ratio in this experiment helped to fix the minimum amendment for better growth of the planted plant.

\section{ACKNOWLEDGEMENTS}

Authors are thankful and grateful to Director, CSIR-Central Institute of Mining and Fuel Research (CIMFR), Dhanbad, Jharkhand, India for the scientific and intellectual support. Authors are very much thankful for getting valuable and additional support received from the Soil Testing Laboratory, Agriculture Department, Balaghat for soil analysis and Department of Biotechnology, Sardar Patel College of Technology, Balaghat, Madhya Pradesh, India. Lastly, but very important thank render to Malanjkhand Copper Project (MCP, HCL) officials for providing copper overburden dump spoil material, nearby soil and location maps for conducting this pot experiment at SPCT, Balaghat, college campus.

\section{REFERENCES}

[1] Alaoui-Sosse, B., P. Genet, F. Vinit-Dunand, M.L. Taussant, D.Epran and P.M. Badot(2004),

"Effect of copper on growth in cucumber plants and its relationships with carbohydrate accumulation and changes in ion contents". Plant Sci., 166, 2004, 1213-1218

[2] Tan Y, Zongsuo L, Shao H B and Feng D. (2006), "Effect of water deficits on the activity of antioxidative enzymes and osmoregulation among three different genotypes of Radix astragali at seeding stage". Coll. Surf. B: Biointerf. 49: 60-65.

[3] Kovacik J, Backor M and Kadukova J. (2008), "Physiological responses of Matricaria chamomilla to cadmium and copper excess”. Environ. Toxicol. 23:123-130.

[4] Passariello B, Giuliano V, Quaresima S, Barbaro M, Caroli S, Forte G, Garelli G and Iavicoli I, (2002), "Evaluation of the environmental contamination at an abandoned mining site". J. Microchem. 73:245-250.

[5] Chen L M, Lin C C and Kao C H. (2000), "Copper toxicity in rice seedlings: Changes in antioxidative enzyme activities, $\mathrm{H} 2 \mathrm{O} 2$ level and cell wall peroxides activity in roots". Bot. Bull. Acad. Sin. 41: 99-103.

[6] Demirevska-kepova K, Simova-Stoilova L, Stoyanova Z, Holzer $R$ and Feller U. (2004). "Biochemical changes in barely plants after excessive supply of copper and manganese". Environ. Exp. Bot. 52: 253-266.

[7] Raven J A, Evans $M C W$ and Korb R E. (1999). "The role of trace metals in photosynthetic electron transport in O2-evolving organisms”. Photo. Res. 60: 111-149.

[8] Haslam E. (1993). Shikimic Acid: Metabolism and Metabolites. Wiley, Chichester, UK.

[9] Ven Murthy M R, Ranjekar, P K, Ramassamy $C$ and Deshpande M. (2010). "Scientific Basis for the Use of Indian Ayurvedic Medicinal Plants in the Treatment of Neurodegenerative Disorders": Ashwagandha.Cent. Nerv. Sys. Agen. in Med. Chem. 10: 238-246. 
[10] Anupama Singh, Kapil Lawrence, Swati Pandit and Reena S. Lawrence (2014), "Response Of Leaves, Stems And Roots Of Withania Somnifera To Copper Stress", International Journal of Plant, Animal and Environmental Sciences (IJPAES), Vol.4 issue.3, July-September, 2014:pp.6067.

[11] Sharma, Rajesh Kumar and Madhulika Agrawal (2005). "Biological effects of heavy metals: An overview”. J. Environ. Biol., 26, 2005, 301-313.

[12] Van Assche, F. and H. Clijters (1990). "Effects of metals on enzyme activity in plants". Plant Cell Environment, 13, 1990, 195-206.

[13] Horrison, M.D., C.E. Jones and C.T. Domeron (1999). "Copper chaperones function structure and copper-binding properties”. JBIC, 4, 1999, 145-153.

[14] Burkhead J L, Reynolds K A G, Abdel-Ghany S E, Cohu C M and Pilon M. (2009). "Copper homeostasis". New Phytol. 182:799-816.

[15] Wilkins D A. (1978). "The measurement of tolerance to edaphic factors by means of root growth”. New Phytol. 80: 623-33.

[16] Michaud A M, Chappellaz C and Hinsinger P. (2007). "Copper phytotoxicity affects root elongation and Iron nutrition in Durum Wheat (Triticum durum L.) '”. Plant and Soil 310:151-165. [17] Neelkanthan and Mehta (1962), J. Indian Soc. Soil Sci. 32:39

[18]Agrwal, H.P and D.D Motiramani, (1966), J. Indian Soc. Soil Sci. 14:162

[19] Rai, M.M. and Mishra, M.K. (1967). "Available copper in Madhya Pradesh soils". Journal of Indian Society of Soil Science, 15, 49-51.

[20]Sakal, R, A.P. Singh and S.P.Singh, (1988), J.Indian Soc. Soil Sci.36:59

[21]Kanwar, J.S (1954) J.Indian Soc. Soil Sci. 2:73

[22]Rai, M.M., A.R.Pal, B.P.Chimania, D.B.Shitole and P.Vakh. (1972). J.Indian Soc.Soil Sci.20:128.

[23]Maji, B., S. Chatterjee and B.K.Bandyopadhyay, (1993). J. Indian Soc. Soil Sci.41 :468.

[24] Mohnish Pichhode and Kumar Nikhil (2015) "Effect of Copper Dust on Photosynthesis Pigments Concentration in Plants Species”, International Journal of Engineering Research and Management (IJERM), Vol.2, No.2, February, 2015 (Online) 63-66.

[25] Mohnish Pichhode and Kumar Nikhil (2015), "Effect of Copper Mining Dust on the Soil and vegetation in India: A Critical Review”, International Journal of Modern Sciences and Engineering Technology (IJMSET), Vol.2, No.2, February, 2015 (Online) 73-76.

[26] Jyotish Katare, Mohnish Pichhode and Kumar Nikhil (2015), Effect of Different Mining Dust on the Vegetation of District Balaghat, M.P - A Critical Review International Journal of Science and Research (IJSR), ISSN (Online): 2319-7064, August, 2015, 603-607. 